\title{
SUPERVISI AKADEMIK OLEH KEPALA MADRASAH DALAM MENINGKATKAN PROFESIONALISME GURU
}

\section{Tasnim*, Muntari, Sukardi}

Program Studi Magister Administrasi Pendidikan Pascasarjana Universitas Mataram, Indonesia. *Corresponding Author: nimspd@gmail.com

\section{Article History}

Received : May $02^{\text {th }}, 2021$

Revised : May $15^{\text {th }}, 2021$

Accepted : May $27^{\text {th }}, 2021$

Published : May $31^{\text {th }}, 2021$

\begin{abstract}
Supervisi akademik adalah serangkaian kegiatan untuk membantu guru mengembangkan kemampuannya dalam mengelola proses pembelajaran dan pencapaian tujuan pembelajaran. Penelitian ini bertujuan untuk mengetahui pelaksanaan supervisi akademik oleh kepala madrasah dalam meningkatkan profesionalisme guru. Penelitian ini menggunakan pendekatan kualitatif dengan metode studi kasus. Sedangkan pengumpulan data dilakukan melalui observasi, wawancara dan studi dokumentasi. Subyek penelitian adalah kepala madrasah dan guru-guru di MI Hamzanwadi I Pancor. Hasil analisis data menunjukkan bahwa pelaksanaan supervisi akademik oleh kepala madrasah dalam meningkatkan profesionalisme guru di MI Hamzanwadi I Pancor menggunakan pendekatan kolaboratif yaitu secara langsung dan secara tidak langsung. Teknik-teknik supervisi akademik yang digunakan adalah teknik individual dan teknik kelompok dengan menggunakan strategi lesson study.
\end{abstract}

Keywords: supervisi akademik; profesionalisme guru.

\section{PENDAHULUAN}

Keberadaan dan ketersediaan guru profesional terus menerus ditingkatkan walaupun masih banyak guru yang mengajar di sekolah tidak sesuai dengan kualifikasi akademik yang dimilikinya (Rasyid, 2015). Salah satu fakta yang menunjukkan kurangnya profesionalisme guru adalah, misalnya, adanya guru lulusan pendidikan agama mengajar mata pelajaran olah raga dan sebagainya. Contoh riil adalah, sampai saat ini, terdapat 15 orang guru olah raga yang qualifikasinya paralel yang mengajar mata pelajaran olah raga pada 230 madrasah ibtidaiyah di Lombok Timur, termasuk yang mengajar mata pelajaran ini di MI Hamzanwadi I Pancor.

Walaupun termasuk dalam kategori guru profesional, sikap profesionalisme guru harus terus dikembangkan dan ditingkatkan (Ambarita, 2015). Hal ini dikarenakan sikap profesionalisme dipengaruhi oleh faktor internal dan eksternal guru (Inayatullah, 2011, Ritonga, Siddik, \& Khadijah, 2017). Faktor internal yang mempengaruhi sikap profesionalisme antara lain adalah motivasi kerja, motivasi berprestasi dan lainnya (Sartika \& Muchtar, 2014), sedangkan faktor eksternal yang mempengaruhi sikap profesionalisme antara lain adalah perkembangan kurikulum dan supervisi akademik yang dilakukan oleh kepala sekolah (Herlita, Wijaya, \& Saputra, 2018).

Supervisi akademik dilakukan sebagai upaya untuk meningkatkan dan mengembangkan kemampuan guru agar dapat melaksanakan tugasnya secara profesional (Mujiyana, 2019). Supervisi diperlukan dalam proses pendidikan berdasarkan dua hal penting. Pertama, perkembangan kurikulum yang merupakan gejala kemajuan pendidikan. Perubahan tersebut sering menimbulkan perubahan-perubahan struktur maupun fungsi kurikulum. Pelaksanaan kurikulum tersebut memerlukan penyesuaian yang terus menerus dengan keadaan nyata di lapangan. Hal ini berarti bahwa guru-guru senantiasa harus mengembangkan kreativitasnya agar pendidikan berdasarkan kurikulum itu dapat terlaksana dengan baik. Kedua, pengembangan personel, pegawai atau karyawan senantiasa merupakan upaya yang terus menerus dalam suatu organisasi. Demikian pula halnya dengan sekolah, kepala sekolah, guru, tenaga tata usaha memerlukan peningkatan karirnya, pengetahuan dan keterampilannya (Daryanto, 2011).

Pekerjaan yang bersifat profesional adalah pekerjaan yang hanya dapat dilakukan oleh orang yang khusus dipersiapkan (Helmi, 2015). Guru yang profesional harus memiliki kemampuan dan keahlian dalam bidang keguruan, sehingga ia mampu melakukan tugas dan fungsinya sebagai 
guru secara maksimal. Guru adalah seorang pendidik, pembimbing, pelatih, dan pemimpin yang dapat menciptakan iklim belajar yang menarik, memberi rasa aman, nyaman dan kondusif dalam kelas (Tarhid, 2015). Keberadaan guru di tengah-tengah siswa dapat mencairkan suasana kebekuan, kekakuan, dan kejenuhan belajar yang terasa berat diterima oleh para siswa. Kondisi seperti ini tentunya memerlukan keterampilan dari seorang guru, dan tidak semua mampu melakukannya. Menyadari hal itu, maka penulis menganggap bahwa keberadaan guru profesional sangat diperlukan.

Penelitian mengenai supervisi akademik pernah dilakukan oleh beberapa peneliti sebelumnya, diantaranya penelitian yang dilakukan oleh Zakso \& Radiana (2012), pelaksanaan supervisi akademik dinilai dapat meningkatkan kinerja atau profesionalisme guru dalam melaksanakan pembelajaran. Penelitian lain (Muhajirin dkk, 2018) menunjukkan adanya hubungan yang signifikan antara gaya kepemimpinan kepala madrasah dengan motivasi kerja guru madrasah. Adapun perbedaan penelitian ini dengan penelitian yang lain adalah dari segi pelaksanaan supervisi akademik yaitu pendekatan yang digunakan yaitu pendekatan kolaboratif yaitu secara tidak langsung dan secara langsung kunjungan kelas. Selain itu juga menggunakan pendekatan lesson study, yaitu pola perbaikan pembelajaran melalui tiga tahapan yaitu plan (merencanakan), do (melaksanakan), dan see (refleksi) (Muntari dkk, 2021).

Berdasarkan hal tersebut, dilakukan penelitian tentang pelaksanaan supervisi akademik oleh kepala madrasah dalam meningkatkan profesionalisme guru di MI Hamzanwadi 1 Pancor. Kepala madrasah MI Hamzanwadi I Pancor secara rutin melakukan supervisi akademik yang berupa supervisi admistrasi pembelajaran, pelaksanaan pembelajaran, dan penilaian hasil pembelajaran.

\section{METODE}

Penelitian ini menggunakan pendekatan kualitatif dengan menggunakan prosedur desain penelitian studi kasus. Penelitian ini berfokus pada pelaksanaan supervisi akademik oleh kepala madrasah dalam meningkatkan profesionalisme guru di MI Hamzanwadi I Pancor dengan subfokus penelitian: (1) perencanaan supervisi akademik kepala madrasah dalam meningkatkan profesionalisme guru, (2) pelaksanaan supervisi akademik oleh kepala madrasah dalam meningkatkan profesionalisme guru, (3) evaluasi supervisi akademik oleh kepala madrasah dalam meningkatkan profesionalisme guru, (4) tindak lanjut supervisi akademik oleh kepala madrasah dalam meningkatkan profesionalisme guru di MI Hamzanwadi I Pancor.

Penelitian ini dilaksanakan di Madrasah Ibtidaiyah Hamzanwadi I Pancor, Kecamatan Selong Kabupaten Lombok Timur Provinsi Nusa Tenggara Barat. Data penelitian terdiri dari data primer dan data sekunder. Data primer diperoleh melalui observasi dan wawancara langsung dengan subyek dan informan penelitian berupa informasi tentang pelaksanaan supervisi akademik kepala madrasah dalam meningkatkan profesionalisme guru di MI Hamzanwadi I Pancor Lombok Timur. Data sekunder diperoleh melalui metode studi dokumentasi yang melekat pada dokumen, gambar, dan video yang berkaitan dengan pelaksanaan supervisi akademik kepala madrasah dalam meningkatkan profesionalisme guru di MI Hamzanwadi I Pancor.

Sumber data dalam penelitian ini dari subyek dan informan serta dokumen. Subyek adalah orang tempat melekatnya supervisor dalam hal ini kepala MI Hamzanwadi I Pancor yang sekarang sudah menjadi pengawas, sedangkan informan yaitu orang-orang yang dianggap mampu untuk memberikan informasi/data penelitian, yaitu guru di MI Hamzanwadi I Pancor. Teknik pengumpulan data dilakukan secara sirkuler dengan menggunakan tiga pendekatan observasi, wawancara mendalam, dan dokumentasi. Prosedur analisis data dilakukan dengan cara reduksi data, display data, dan verifikasi. Pengecekan dilakukan dengan empat kriteria yang digunakan, yaitu derajat kepercayaan (credibility), keteralihan (transferability), dan kepastian (confirmability).

\section{HASIL DAN PEMBAHASAN}

Perencanaan supervisi merupakan langkah awal dalam implementasi supervisi. Perencanaan yang baik akan menghasilkan program yang baik pula. Oleh karenanya banyak hal yang perlu dipertimbangkan dalam perencanaan supervisi. Perencanaan program supervisi disusun secara rutin bersamaan dengan penyusunan program tahunan madrasah berdasarkan tujuan supervisi yakni memberikan bantuan profesional kepada guru guna meningkatkan profesionalisme guru 
dan perbaikan kualitas pembelajaran. Program supervisi yang telah disusun disosialisasikan kepada guru-guru agar mereka dapat mempersiapkan apa yang dibutuhkan dalam pelaksanaan supervisi (wawancara subyek, 1401-2020).

Kegiatan supervisi akademik yang dilakukan kepala madrasah pada pelaksanaan pembelajaran di MI Hamzanwadi I Pancor adalah dengan pendekatan kolaboratif. Supervisi akademik dilaksanakan baik secara langsung maupun tidak langsung di dalam kelas. Pelaksanaan supervisi dilakukan dengan terlebih dahulu memeriksa admistrasi pembelajaran guru dan supervisi kunjungan kelas atau observasi kelas (wawancara subyek, 14-01-2020).

Guru-guru juga mengungkapkan hal yang sama dengan kepala madrasah tentang pendekatan supervisi yang dilakukan, yakni dengan pendekatan kolaboratif (wawancara informan 1, 14-01-2020). Seorang guru mengungkapkan bahwa pendekatan yang dilakukan dalam pelaksanaan supervisi akademik terkadang secara langsung masuk ke kelas dan adakalanya supervisi tidak langsung, yaitu dengan memeriksa admistrasi pembelajaran (wawancara informan 3, 18-01-2020).

Berdasarkan pernyataan di atas kepala madrasah dalam pelaksanaan supervisi akademik menggunakan pendekatan kolaboratif yaitu secara tidak langsung dan secara langsung kunjungan kelas. Melalui kunjungan kelas ini, kepala madrasah dapat mengetahui kesulitan yang dihadapi oleh guru, dan memeriksa admistrasi pembelajaran. Hal ini sesuai dengan pendapat Purwanto (2010:120) mengatakan dengan kunjungan kelas supervisor melihat dan mengamati guru mengajar apakah sudah memenuhi syarat-syarat didaktik atau metodik yang sesuai, membimbing guru mengatasi problem yang timbul di dalam kelas.

Berdasarkan hasil wawancara dengan kepala madrasah, terungkap bahwa teknik-teknik pelaksanaan supervisi akademik oleh kepala MI Hamzanwadi I Pancor dilaksanakan melalui pertemuan individual dan pertemuan kelompok. Pertemuan individual meliputi: observasi kelas, kunjungan kelas, percakapan pribadi, menyeleksi berbagai sumber materi untuk mengajar. Sedangkan pertemuan kelompok meliputi: rapat supervisi, diskusi kelompok, tukar-menukar pengalaman, workshop, seminar dan kegiatan di KKG (wawancara subyek, 14-01-2020). Ini sesuai dengan pendapat Purwanto (2010:120) teknik supervisi dapat digolongkan menjadi dua, yakni teknik perseorangan dan teknik kelompok".

Sementara guru-guru juga mengatakan teknik supervisi yang diterapkan dalam pelaksanaan supervisi, dimana guru (informan 1) mengatakan:

"Teknik yang dilakukan kepala madrasah dalam pelaksanaan supervisi akademik di madrasah kami adalah melalui teknik pertemuan individual dan teknik pertemuan kelompok. Teknik individual meliputi: kunjungan kelas, percakapan pribadi, teknik bersifat kelompok meliputi: rapat supervisi, dan kegiatan di kelompok kerja guru (KKG)" (wawancara informan 1, 14-01-2020).

Hal senada juga tentang teknik pelaksanaan supervisi dinyatakan oleh guru (informan 2) mengatakan:

"Kepala madrasah melaksanakan teknik supervisi kelompok dan individual di madrasah kami melalui pertemuan kelompok dan individual. Kepala madrasah memecahkan permasalahan yang ditemukan dalam proses pembelajaran. Temuan tersebut ditindaklanjuti secara wajar tanpa dirasakan sebagai pengawasan. Teknik kelompok dilakukan kepala madrasah apabila ditemukan masalah yang sama" (wawancara informan 2, 17-02-2020).

Seorang guru (informan 3) menambahkan teknik pelaksanaan supervisi yang dilakukan kepala madrasah dapat membantu semua masalah pembelajaran yang ditemukan. Oleh karena itu pelaksanaan supervisi akademik perlu dilakukan secara terus menerus dan berkelanjutan. Sebagaimana diketahui tujuan supervisi akademik adalah untuk meningkatkan kemampuan profesionalisme guru dalam memperbaiki kegiatan proses pembelajaran (wawancara informan 3, 18-01-2020).

Berdasarkan keterangan yang terungkap bahwa kepala madrasah melaksanakan supervisi akademik dalam rangka meningkatkan profesionalisme guru. Berkaitan dengan hal tersebut kepala madrasah menggunakan teknikteknik supervisi akademik meliputi: pertemuan kelompok, dan pertemuan individual. Pertemuan individual antara lain: kunjungan kelas, observasi kelas, percakapan pribadi. Pertemuan kelompok terdiri dari: rapat supervisi, diskusi, tukar menukar pengalaman. Melalui teknik-teknik ini kepala madrasah dapat membantu guru untuk mengatasi kesulitan-kesulitan dalam kegiatan 
pembelajaran di kelas. Pelaksanaan supervisi akademik dengan menggunakan teknik-teknik tersebut dipandang perlu untuk diterapkan dan bermanfaat untuk memotivasi serta mengarahkan perhatian guru-guru terhadap kegiatan belajar mengajar yang lebih efektif dan efesien, sehingga dapat berpengaruh terhadap peningkatan profesionalisme guru.

Teknik supervisi akademik ini sama dengan hasil penelitian Dalwi dkk (2012) bahwa teknik yang dikembangkan oleh pengawas dalam melaksanakan supervisi akademik di SMP 1 Bengkayang adalah teknik supervisi individual dan teknik kelompok. Hal tersebut sesuai dengan pandangan yang dikemukakan oleh Makawimbang (2011) bahwa berbagai macam teknik dapat dipergunakan oleh supervisor dalam membantu guru meningkatkan situasi belajar mengajar baik secara kelompok maupun secara perorangan. Teknik supervisi kelompok adalah teknik yang dilakukan supervisor dalam usaha pembinaan guru secara bersama-sama di dalam suatu perkumpulan, misalnya rapat guru, diskusi, workshop, bimbingan kelompok, dan kegiatan kelompok kerja guru (KKG). Teknik individual adalah suatu teknik yang dilakukan supervisor kepada personal guru untuk meningkatkan mutu pengajaran di madrasah. Teknik supervisi individual meliputi kunjungan kelas, observasi kelas, percakapan pribadi.

Berdasarkan pendapat di atas dapat disimpulkan bahwa pelaksanaan supervisi akademik dilakukan dengan pendekatan kolaboratif dengan menggunakan teknik-teknik supervisi akademik yaitu teknik perseorangan (individual) dan teknik kelompok. Dengan penggunaan teknik supervisi yang dilakukan kepala madrasah dapat membina guru dan mengatasi masalah-masalah yang terjadi pada kegiatan pembelajaran yang dihadapi guru di kelas baik yang menyangkut perumusan perangkat pembelajaran maupun dalam mengimplementasikan kegiatan pembelajaran terhadap siswa di kelas. Teknik-teknik supervisi yang dilakukan kepala madrasah baik secara individual maupun kelompok bermanfaat untuk meningkatkan profesionalisme guru pada perbaikan proses belajar mengajar dan berimbas kepada peningkatan mutu lulusan.

Supervisi akademik yang dilakukan di MI Hamzanwadi I Pancor juga menggunakan pendekatan lesson study. Lesson Study merupakan kegiatan terus menerus yang tiada henti dan merupakan upaya untuk mengaplikasikan prinsip-prinsip total quality management, yaitu memperbaiki proses dan hasil pembelajaran siswa secara terus-menerus berdasarkan data. Lesson study dilaksanakan dalam tiga tahap, yakni plan, do, dan see. Kepala madrasah (subjek) mengatakan:

"Pendekatan supervisi akademik juga kami lakukan dengan strategi lesson study, yakni terlebih dahulu memilih guru model, mata pelajaran, observer, dan supervisor. Observer diambil dari guru-guru MI Hamzanwadi I Pancor dan beberapa dosen dari Universitas Hamzanwadi Pancor. Pelaksanaannya melalui tiga tahapan yaitu plan (merencanakan), do (melaksanakan), dan see (merefleksikan). Lesson study ini kami lakukan sekali sebulan" (wawancara subyek, 11-09-2020).

Guru (informan 1) juga mengatakan hal yang sama dengan kepala madrasah tentang strategi lesson study menyatakan bahwa strategi yang dilakukan oleh kepala madrasah dalam pelaksanaan supervisi akademik di madrasah kami dilakukan melalui strategi lesson study, yang diawali dengan pemilihan guru model, mata pelajaran, dan tim observer (wawancara informan 1, 11-09-2020).

Hal senada juga diungkapkan oleh guru (informan 2) tentang strategi pelaksanaan supervisi akademik mengatakan:

"Kepala madrasah melaksanakan stategi lesson study di madrasah kami. Pada saat plan (merencanakan) tim yang sudah dibagi sesuai mata pelajaran bertugas merancang langkahlangkah pembelajaran dan bahan ajar yang akan disampaikan, kemudian pelaksanaannya di kelas, setelah itu diadakan refleksi. Pada saat refleksi observer memberi masukan tentang bagaimana situasi pada saat pelaksanaan pembelajaran" (wawancara informan 2, 11-09-2020).

Hal yang sama juga diungkapkan guru (informan 3) tentang strategi pelaksanaan supervisi akademik, bahwa dengan strategi lesson study bisa meningkatkan profesiolisme guru dimana guru dituntut utuk lebih kreatif baik waktu merencanakan langkah-langkah pembelajaran dan menyiapkan media yang sesuai dengan materi yang diajarkan pada pelaksanaan pembelajaran, melaksanakan pembelajaran, dan mengevaluasi. Strategi lesson study juga membuat siswa lebih aktif dalam mengikuti pembelajaran, anak yang tadinya diam saja 
menjadi ikut aktif dalam pembelajaran (wawancara informan 3, 11-09-2020).

Berdasarkan keterangan kepala madrasah dan guru tersebut maka dapat diketahui bahwa strategi supervisi akademik menggunakan lesson study yang diawali dengan pemilihan guru model, mata pelajaran, dan tim observer. Pelaksanaan lesson study melalui tiga tahapan yaitu plan (merencanakan), do (melaksanakan), dan see (refleksi). Masing-masing tim menyiapkan langkah-langkah pembelajaran dan bahan ajarnya, guru dituntut untuk lebih kreatif dalam merancang langkah-langkah pembelajaran dan perumusan bahan ajar, melaksanakan, dan mengevaluasi pembelajaran. Pada saat pelaksanaan pembelajaran siswa tidak terpengaruh dengan keberadaan observer yang banyak. Strategi lesson study dapat meningkatkan motivasi siswa, siswa merasa senang dalam pembelajaran dan dapat meningkatkan profesionalisme guru seperti pemahaman guru terhadap peserta didik, perancangan dan pelaksanaan pembelajaran, evaluasi hasil belajar, dan pengembangan peserta didik untuk mengaktualisasikan berbagai potensi yang dimiliki.

Hasil penelitian ini didukung hasil penelitian Nugroho \& Hendayana (2011) bahwa pelaksanaan supervisi akademik berbasis lesson study sangat membantu kemampuan guru dalam meningkatkan mutu pembelajaran di kelas. Hal ini sesuai dengan pendapat Satori (dalam Suhardan, 2010) menyatakan bahwa supervisi akademik adalah kegiatan yang berurusan dengan perbaikan dan peningkatan proses dan hasil pembelajaran. Hikmawati dkk (2020) telah menyosialisakan lesson study for learning community (LSLC) sebagai upaya peningkatan mutu pembelajaran IPA di SMP Kota Mataram. Wadi dkk (2020) telah melaksanakan pembelajaran kolaboratif IPS multikultural dengan pola lesson study untuk memperkuat pendidikan karakter siswa. Pendekatan lesson study sangat relevan dengan amanat Undangundang Nomor 14 tahun 2005 tentang Guru dan Dosen yang menyatakan bahwa dalam melaksanakan tugas keprofesionalan guru berkewajiban: (a) merencanakan pembelajaran, melaksanakan proses pembelajaran yang bermutu, serta menilai dan mengevaluasi hasil pembelajaran, (b) meningkatkan dan mengembangkan kualifikasi akademik dan kompetensi secara berkelanjutan sejalan dengan perkembangan ilmu pengetahuan, teknologi dan seni.

Untuk kelancaran pelaksanaan supervisi diperlukan instrumen supervisi akademik. Instrumen ini digunakan sebagai alat pendukung untuk mengungkapkan kendala-kendala yang dihadapi guru dalam kegiatan pembelajaran. Berdasarkan hasil wawancara dengan kepala madrasah (subjek) mengenai instrumen yang digunakan dalam pelaksanaan supervisi akademik, diantaranya adalah instrumen supervisi rencana pelaksanaan pembelajaran dan instrumen untuk pelaksanaan proses pembelajaran. Intrumen tersebut dirumuskan dan dikembangkan bersama guru (wawancara subyek, 14-01-2020).

Penggunaan instrumen supervisi akademik ini diungkapkan juga oleh guru (informan 3) yang mengatakan bahwa dalam penyusunan program supervisi, kepala madrasah menyertakan rancangan instrumen berupa alat penilaian supervisi akademik guru (wawancara informan 3, 17-02-2020).

Berdasarkan keterangan di atas dapat diketahui bahwa pelaksanaan supervisi akademik dilengkapi dengan instrumen rencana pelaksanaan pembelajaran sebagai pendukung pelaksanaan supervisi terhadap kegiatan proses pembelajaran yang dilakukan guru di kelas. Instrumen dirumuskan dan dikembangkan bersama dengan guru, dan disosialisasikan. Tujuannya agar guru mengetahui apa yang harus dipersiapkan dalam pelaksanaan supervisi akademik yang dilakukan kepala madrasah. Ini sesuai dengan pendapat Arikunto (2009) suatu instrumen dikatakan baik apabila mampu mengevaluasi sesuatu yang dievaluasi sesuai dengan keadaan sebenarnya.

Pelaksanaan supervisi akademik dipandang perlu diterapkan dan bermanfaat untuk memotivasi serta mengarahkan perhatian guru-guru terhadap kegiatan belajar mengajar yang lebih efektif dan efisien, sehingga dapat mempengaruhi peningkatan profesionalisme guru. Sebagaimana yang diungkapkan kepala madrasah (subjek), bahwa pelaksanaan supervisi akademik dapat meningkatkan profesinalisme guru. Subyek mengatakan:

"Dengan pelaksanaan supervisi akademik dapat meningkatkan profesionalisme guru di madrasah yang saya pimpin. Dari pengamatan yang dilakukan melalui teknik kunjungan kelas ditemukan semua guru sudah dapat merumuskan analisis hari efektif, program tahunan, program 
semester, merumuskan kriteria ketuntasan minimal (KKM) dan bisa membuat rencana persiapan pembelajaran (RPP) sesuai standar kompentesi (SK), kompetensi dasar (KD) serta mengimplementasikan kepada siswanya masingmasing" (wawancara subyek, 14-01-2020).

Hasil pengamatan dan dokumentasi yang tersedia di madrasah menunjukkan bahwa supervisi yang dilakukan kepala madrasah telah membawa perubahan dan meningkatkan profesionalisme guru pada kegiatan proses pembelajaran yang dilakukan guru di kelas masing-masing.

Guru juga mengungkapkan hal yang sama, pelaksanaan supervisi akademik dapat meningkatkan profesionalisme mereka. Pelaksanaan supervisi akademik dan penggunaan teknik-teknik supervisi dapat membuka cakrawala berfikir guru dalam hal penyusunan semua perangkat pembelajaran yang dituntut sebagai pendukung kegiatan proses belajar mengajar atau kegiatan tatap muka dengan siswa di kelas, guru terbantu dan termotivasi serta berdampak positif terhadap peningkatan mutu belajar siswa dan meningkatkan profesionalisme guru (wawancara informan 2, 14-01-2020).

Berdasarkan informasi di atas, diketahui bahwa pelaksanaan supervisi akademik yang dilakukan kepala madrasah berdampak positif terhadap peningkatan profesionalisme guru serta membuka wawasan berfikir guru menyangkut dengan penyusunan perangkat pembelajaran, pelaksanaan, dan evaluasi pembelajaran. Hal ini membuktikan bahwa hasil penelitian ini perlu ditindaklanjuti karena memberikan dampak yang nyata untuk meningkatkan profesionalisme guru. Guru-guru yang mempunyai kelemahan dalam menyusun dan mengembangkan perangkat pembelajaran, mengimplementasikan kegiatan proses pembelajaran, diberikan kesempatan untuk mengikuti pelatihan berupa penguatan dan penghargaan kepada guru yang telah memenuhi standar, teguran yang bersifat membangun diberikan kepada guru yang belum memenuhi standar (Priansa dan Somad, 2014).

\section{KESIMPULAN}

Berdasarkan uraian dan pembahasan hasil penelitian di atas menegaskan kesimpulan bahwa pelaksanaan supervisi akademik oleh kepala madrasah dalam meningkatkan profesionalisme guru MI Hamzanwadi I Pancor dimulai dengan perencanaan supervisi akademik yang dilakukan setiap tahun bersamaan dengan penyusunan program tahunan madrasah. Pelaksanaan supervisi akademik dilakukan dengan pendekatan kolaboratif yaitu secara tidak langsung dan secara langsung melaui kunjungan kelas. Teknik-teknik yang dilakukan adalah teknik kelompok dan teknik individual serta strategi lesson study. Evaluasi dilakukan setelah selesai pelaksanaan supervisi akademik dengan cara memanggil guru yang sudah disupervisi secara perorangan dan diberikan masukan sesuai hasil temuan pada saat pelaksanaan supervisi. Hasil supervisi akademik ditindaklanjuti dengan pemberian penguatan dan penghargaan kepada guru-guru yang telah melakukan perbaikan pembelajaran, serta memberi kesempatan kepada guru-guru lain untuk mengembangkan diri melalui diskusi dan atau mengikuti pelatihan.

Hasil penelitian ini direkomendasikan untuk diterapkan juga pada spektrum dan tingkat pendidikan yang sama ataupun juga yang setingkat di bawah dan di atas obyek penelitian ini. Hal ini berarti bahwa profesionalisme guru dapat dibina, dikembangkan dan dibangun dengan memaksimalkan peran supervisi akademik yang dilakukan oleh kepala sekolah karena supervisi akademik yang dilakukan kepala madrasah (obyek penelitian ini) ditemukan berdampak positif terhadap peningkatan profesionalisme guru. Disamping itu, ditemukan pula kegiatan supervisi seperti ini dapat serta membuka wawasan berfikir guru terkait dengan pengembangan pembelajaran dan perangkat pendukungnya.

\section{UCAPAN TERIMA KASIH}

Ucapan terima kasih disampaikan kepada Dr. H. Sudirman Wilian, M.A, selaku ketua program studi Magister Administrasi Pendidikan Universitas Mataram dan Dra Zurriatun Sholihah, M.Pd, selaku kepala MI Hamzanwadi I Pancor, yang telah menyediakan waktu yang banyak di tengah-tengah kesibukan beliau sebagai informan utama penelitian ini.

\section{REFERENSI}

Ambarita, B. (2015). Upaya Peningkatan Sikap Profesional Guru Melalui Peningkatan Kebiasaan Membaca. Jurnal Cakrawala Pendidikan, (2), 314-325. https://doi.org/10.21831/cp.v0i2.4239 
Arikunto, S. (2009). Penilaian Pendidikan, Jakarta: Depdikbud.

Daryanto, H. (2011). Media Pembelajaran. Bandung: Satu Nusa.

Helmi, J. (2015). Kompetensi Profesionalisme Guru. Jurnal Pendidikan, 7(2), 319-336. Retrieved from http://journal.staihubbulwathan.id/index.p hp/alishlah/article/view/43/38

Herlita, H., Wijaya, C., \& Saputra, E. (2018). Profesional Guru Smk Swasta Sekecamatan Medan Marelan. $A T$ TAZAKKI, 2(2), 187-199.

Hikmawati, Ramdani, A., Hadiprayitno, G., Muntari, \& Haris, M. (2020). Sosialisasi Lesson Study for Learning Community (LSLC) Sebagai Upaya Peningkatan Mutu Pembelajaran IPA di SMP Kota Mataram. Jurnal Pengabdian Masyarakat Sains Indonesia (JPMSI). 2(2), 108-112.

Inayatullah. (2011). Kontribusi Faktor-Faktor Internal Dan Eksternal Terhadap Peningkatan Kinerja Profesional Guru. Jurnal FKIP: REGION, 3(1), 51-74. Retrieved from http://www.ejournalunisma.net/ojs/index.php/region/article/vi ew/460

Makawimbang, J.H. (2011). Supervisi dan Peningkatan Mutu Pendidikan. Bandung: Alfabeta.

Muhajirin, Wildan, \& Sukardi (2018). Hubungan antara Gaya Kepemimpinan Kepala Sekolah dan Budaya Organisasi Sekolah dengan Motivasi Kerja Guru Madrasah Aliyah Swasta Se Kabupaten Lombok Tengah. Jurnal Pendidikan Sosial Keberagaman, 5 (2), 24-36.

Mujiyana. (2019). Upaya Meningkatkan Kompetensi Guru melalui Supervisi Akademik Teknik Individual Kunjungan Kelas di MIN 1 Gunungkidul Tahun Ajaran 2018/2019. Jurnal Pendidikan Madrasah, 4(1), 67-76.

Muntari, Muti'ah, Al Idrus, S.W., \& Supriadi. (2021). Pendampingan Implementasi
Pembelajaran Guided Discovery Melalui Lesson Study for Learning Community (LSLC) untuk Peningkatan Kemampuan Berpikir Kritis Kimia Siswa SMA Zonasi Narmada Kabupaten Lombok Barat. Jurnal Pengabdian Magister Pendidikan IPA, 4(1), 143-148.

Nugroho, L. A., \& Hendayana, S. (2011). Penerapan Lesson Study Berbasis Sekolah untuk Melaksanakan Supervisi Akademik Pembelajaran Fisika Di SMA1. Jurnal Penelitian Pembelajaran Fisika, 2(1).

Priansa, DJ \& Somad. (2014), Manajemen Supervisi dan Kepemimpinan Kepala Sekolah, Bandung: Alfabeta.

Purwanto, Ngalim. (2011). Administrasi dan Supervisi Pendidikan. Bandung: PT. Rosda Karya.

Rasyid, H. Al. (2015). Analisis Standar Kualifikasi Akademik Guru SD di Kecamatan Kras Kabupaten Kediri. Widyagogik, 1(1), 1-16.

Ritonga, P., Siddik, D., \& Khadijah. (2017). Urgensi Profesionalisme Guru Dalam Proses Pembelajaran Di MIS Nurul Siti Aisyah Ishak Delitua. Edu Riligia, 1(3), 474-486.

Sartika, E., \& Muchtar, B. (2014). Pengaruh Sikap Profesional, Motivasi Kerja dan Disiplin Kerja terhadap Kinerja Guru Sekolah Menengah Atas Negeri Kota Sungai Penuh. Jurnal Riset Manajemen Bisnis Dan Publik, 2(1), 2014.

Suhardan, D. (2010). Supervisi Profesional (Layanan dalam Meningkatkan Mutu Pembelajaran di Era Otonomi Daerah). Bandung: Alfabeta.

Tarhid. (2015). Kepemimpinan Kepala Sekolah dalam Meningkatkan Profesionalisme Guru. Jurnal Kependidikan, 5(2), 141155 .

Zakso, A., \& Radiana, U. (2012). Pelaksanaan supervisi akademik pengawas sekolah sebagai upaya peningkatan profesionalisme guru SMP Negeri 1 
Tasnim et al. (2021). Jurnal Ilmiah Profesi Pendidikan, 6 (1): 159 - 166

DOI: https://doi.org/10.29303/jipp.v6i1.181

Bengkayang (Doctoral dissertation, Tanjungpura University).

Wadi, H., Suryanti, N.M.N., \& Sukardi. (2020). The Collaborative Learning for Multicultural of Social Science with
Lesson Study Pattern for Strengthening Student Character Education. Proceedings of the 1st Annual Conference on Education and Social Sciences (ACCESS 2019). Advances in Social Science, Education and Humanities Research, vol. 465, 322-326. 